\title{
UNIVERSALISME PAULUS MENURUT ALAIN BADIOU: URAIAN DAN TANGGAPAN
}

\author{
Yasintus T. Runesi ${ }^{1}$ \\ Departemen Filsafat Fakultas Ilmu Budaya Universitas Indonesia
}

\begin{abstract}
When people believe that social particularities raise plurality of views in the contemporary society, Badiou introduces the idea of the universality of the singular subject with the aim of overcoming the so-called global village without solidarity. This article is a description of Badiou's thought, which is included in the line of thinkers which moves "small boat of thought" to the subject and the subjectivity of human. In the first section, I will outline Badiou's view about the problem of homogenization, followed by his view of Christianity as an event, which will lead us to his view on the universal singularity that is rooted in the proclamation of St. Paul. At the end, I will propose a critical note on his views in comparison with some philosophers who also spoke about St. Paul. This paper will be closed with a conclusion on the significance of Badiou's thought, in the context of contemporary society's pluralism, especially in Indonesia.
\end{abstract}

KEYWORDS: Badiou, St. Paul, universality, singular subject, pluralism.

ABSTRAK: Ketika semua orang percaya bahwa partikularitas-partikularitas sosial memunculkan pluralitas pandangan di dalam masyarakat

\footnotetext{
1 Pembelajar filsafat. Menyelesaikan pendidikan sarjana filsafat pada Fakultas Filsafat Unika Widya Mandira Kupang dengan skripsi mengenai epistemologi Thomas Aquinas. Selanjutnya, mendapatkan gelar Magister Humaniora dalam bidang Filsafat dari Departemen Filsafat Universitas Indonesia dengan tesis mengenai teori pengakuan Axel Honneth dari Teori Kritis Sekolah Frankfurt. Saat ini tinggal di Cilandak Barat, Jakarta Selatan.
} 
kontemporer, Badiou mengintrodusir gagasannya tentang universalitas subjek singular dengan tujuan mengatasi apa yang disebut sebagai global village tanpa solidaritas. Artikel ini adalah suatu uraian atas pandangan Badiou, yang termasuk dalam barisan pemikir yang menggerakkan "kapal kecil pemikiran" kepada subjek dan subjektivitas manusia. Dalam bagian pertama, saya akan menguraikan pandangan Badiou tentang problem homogenisasi, dilanjutkan dengan pandangannya mengenai kekristenan sebagai sebuah peristiwa, yang akan menghantar kita pada pandangannya mengenai singularitas universal yang diakarkan pada pewartaan St. Paulus. Pada bagian akhir, saya akan mengajukan suatu catatan kritis atas pandangannya dalam perbandingan dengan beberapa filsuf yang berbicara pula mengenai St. Paulus. Tulisan ini akan ditutup dengan satu simpulan mengenai signifikansi pemikiran Badiou, dalam konteks pluralisme masyarakat semasa ini, terutama di Indonesia.

KATA KUNCI: Badiou, St. Paul, universalitas, subjek singular, pluralism.

\section{Pengantar}

Tak dapat disangkal bahwa salah satu aspek dari era postmodern dan apa yang disebut sebagai "pemikiran"nya adalah kembalinya dimensi religius ke dalam beragam bidang kehidupan yang berbeda-beda, dari Kristen dan fundamentalisme lain, melalui keragaman spiritualitas Zaman Baru, mendorong menguatnya sensitivitas religius dalam masyarakat. ${ }^{2}$ Dalam lingkaran pemikir kontinental misalnya, Paulus adalah salah satu sosok yang menjadi titik perhatian pemikir seperti Slavoj Žižek, Giorgio Agamben, Stanisla Brenton, Pier Paolo Pasolini dan Alain Badiou, untuk

2 Slavoj Žižek, The Fragile Absolute or Why is the Christian Legacy worth Fighting for? (London: Verso, 2001), 1. 
menyebut beberapa saja. "Datangnya Paulus" ke dalam diskursus filsafat kontemporer, kalau mau disebut demikian mendorong John D. Caputo untuk menulis bahwa Paulus adalah eine Sache des Denkens. ${ }^{3}$ Paulus adalah sosok yang patut dipikirkan, karena dirinya, pewartaannya secara ontologis seperti anti-fondasionalis dan secara etis berkarakter disruptif, terutama dalam situasi semasa ini, di mana orang berbicara mengenai keterbukaan dan pluralisme.

Posisinya dalam diskursus filsafat-teologi kontemporer lumayan menentukan, sehingga dalam konteks kekristenan misalnya, Žižek menulis bahwa "there is no Christ outside Saint Paul."4 Dalam arus pemikiran yang disebut sebagai religious turn, perhatian yang diarahkan kepada Paulus, tidak dalam kaitannya dengan pemberitaannya mengenai iman akan Kristus Yesus, tetapi terutama menyangkut proyeksinya mengenai apa yang disebut sebagai universalitas kebenaran, berdasarkan keyakinan ( $\tau i \sigma \tau \iota \varsigma) .{ }^{5}$ Bahwa jawaban atas apa itu kebenaran tidak dapat dilepaskan dari subjek tertentu yang meyakininya tanpa kekuatan argumen dan kepandaian rasional. Kebenaran selalu merujuk kepada seseorang yang meyakini sesuatu, dan bahwa tanggungjawab dari subjek tersebut adalah memerkenalkan kebenaran tersebut sehingga bisa dikenal. Kebenaran yang mendorong subjek berjuang, karena hal tersebut memang menentukan dan baik untuk

\footnotetext{
3 John D. Caputo, "Postcards from Paul: Subtraction versus Grafting," St. Paul among the Philosophers, eds. John D. Caputo dan Linda Martín Alcoff (Bloomington: Indiana University Press, 2009), 1.

4 Žižek, The Fragile Absolute, 2.

5 Liddel, Scott, dan Jones mencatat setidaknya terdapat tiga pengertian mengenai kata pistis: Pertama, terkait dengan kepercayaan kepada orang lain. Pengertian ini mengandung empat arti kata yakni: artinya secara umum (1), arti subjektif (2), dalam kaitannya dengan dunia perniagaan (3) dan dalam arti teologis (4). Kedua, terkait dengan pemberian kepercayaan kepada orang lain yang mengandung dua arti yakni menyangkut pemberian jaminan dan sebagai sarana persuasi, argumen, atau pembuktian. Ketiga, terkait dengan tindakan memercayakan. Lih. Henry George Liddell, Robert Scott dan Henry Stuart Jones, A GreekEnglish Lexicon, (Oxford: Clarendon Press, 1996), 1408.
} 
diperjuangkan. ${ }^{6}$

Artikel ini adalah suatu uraian atas pandangan Badiou, yang termasuk dalam barisan pemikir yang menggerakkan "kapal kecil pemikiran"7 kepada subjek dan subjektivitas manusia. ${ }^{8}$ Dalam bagian pertama, saya akan menguraikan pandangan Badiou, dilanjutkan dengan pandangannya mengenai kekristenan sebagai sebuah peristiwa, ${ }^{9}$ yang akan menghantar kita pada pandangannya mengenai singularitas universal yang diakarkan pada pewartaan Paulus. Pada bagian akhir, saya akan mengajukan suatu catatan kritis atas pandangannya dalam perbandingan dengan beberapa filsuf yang berbicara pula mengenai Paulus. Tulisan ini akan ditutup dengan satu simpulan mengenai signifikansi Badiou dalam konteks pluralisme masyarakat semasa ini, terutama di Indonesia.

6 Caputo, "Postcards from Paul," 2.

7 Istilah Joseph Kardinal Ratzinger yang disampaikan dalam Homili Ekaristi pembukaan Konklaf, pada 19 April 2005 lalu. Terdapat dalam Aidan Nichols, The Thought of Pope Benedict XVI: An Introduction to the Theology of Joseph Ratzinger, (London: Burns \& Oates, 2007), 223.

8 Dalam artikel ini, saya berkiblat pada alur yang dibentangkan oleh Badiou dalam artikelnya "St. Paul, Founder of the Universal Subject," St. Paul among the Philosophers, eds. John D. Caputo dan Linda Martin Alcoff (Bloomington: Indiana University Press, 2009). Artikel tersebut dapat dilihat sebagai versi ringkas dari pemikirannya mengenai Paulus sebagaimana dielaborasi dalam bukunya Saint Paul: The Foundation of Universalism, terj. Ray Brassier (Stanford, CA: Stanford University Press, 2003).

9 Peristiwa (event) adalah salah satu kosakata khas Badiou. Peristiwa adalah proses melaluinya kebenaran menjadi hadir. Peristiwa adalah sumber kebaruan bagi sebuah situasi; peristiwalah yang mengangkat dalam dirinya sendiri potensi menuju suatu situasi yang secara radikal berbeda dari dalam situasi itu sendiri. Peristiwa adalah locus dari perubahan yang sebenarnya dari situasi, sebuah retakan imanen yang menginterupsi kontinuitas dan pengulangan yang sama. Kalau ontologi membincangkan sisi konsistensi, maka dalam peristiwa kita membincangkan inkonsistensi. Peristiwa (event) sering dideskripsikan secara berbeda-beda oleh Badiou sebagai "kebaruan radikal," sebagai sesuatu yang "baru secara absolut," "permulaan yang baru (menyangkut teori)," "kekecualian." Peristiwa adalah suatu multiplisitas dalam peristiwa itu sendiri, suatu disrupsi terhadap tatanan ontik. Saya mengikuti rangkuman Hollis Phelps, Alan Badiou: Between Theology and Anti-Theology, (Durham, UK: Acumen, 2013), 52. Gagasan lengkapnya dapat dibaca pada Alain Badiou, Being and Event, terj. Oliver Feltham (London: Continuum, 2005). 


\section{Serbasama sebagai Problem}

Bila kita bertanya, apa gejala ideologi paling mencolok dalam situasi dunia semasa ini? Menurut Badiou, terdapat dua arah pergerakan ideologi yang saling bertolak belakang, namun memiliki efek yang sama: keserbasamaan (homogenisasi). ${ }^{10}$ Di satu sisi, kita menemukan suatu bentuk perluasan otomatisme secara berkelanjutan, yang telah secara brilian diprediksi oleh Marx seabad lebih yang lalu, yakni pengkonfigurasian dunia secara keseluruhan sebagai sebuah pasar global. Menurut Marx, kapitalisme melalui masyarakat kelas borjuis telah mengarahkan masyarakat kepada proses produksi sebagai satu-satunya kategori pemaknaan sosial. Di situ, masyarakat sebagai satu totalitas struktural yang dipandang sebagai satu kesatuan, membangun komunikasi melalui kepemilikan modal sebagai alat mediasi sosial. Akibatnya, mereka yang tidak memiliki modal atau yang tidak memiliki akses kepada sumber-sumber material, dalam hal ini kelas proletar, akan sepenuhnya berada di bawah penindasan para pemilik modal atau kelas borjuis. ${ }^{11}$

Menurut Badiou, bentuk konfigurasi ini berakar dalam suatu penyeragaman abstrak, yakni generalisasi atas unit-unit terkecil yang terdapat dalam dunia. Secara singkat, generalisasi tersebut mengarah kepada singularitas (singularity) yang mengakibatkan ketidaksingularitasan (no singularity) sosial. Satu bentuk penyeragaman yang membawa serta keretakan internal. Jadi, terdapat usaha penyatuan melalui penyeragaman yang dibingkai atau disituasikan oleh sebuah paradigma kesamaan umum (general equivalent). ${ }^{12}$ Dalam istilah Teori Kritis berarti penyeragaman melalui

\footnotetext{
10 Badiou, "St Paul, Founder of the Universal Subject," 27.

11 Bdk. Axel Honneth, "History and Interaction: On the Structuralist Interpretation of Historical Materialism," Althusser: A Critical Reader, ed. Gregory Elliot, terj. Gordon Finlayson (Oxford: Blackwell, 1994).

12 Badiou, “St. Paul, Founder of the Universal Subject," 27.
} 
struktur administratif yang bersifat total, yang menghasilkan satu lingkaran tertutup, yang mendominasi melalui pengendalian budaya dan menghasilkan ketundukan tak sadar atau represi non-terbuka terhadap subjek yang terperangkap di dalam lingkaran setan tersebut. ${ }^{13}$

Di sisi lain, proses homogenisasi hadir melalui proses fragmentasi yang membentuk identitas tertutup atau isolasionis. Suatu masyarakat terkungkung, yang saling menidak satu sama lain. Identitas isolasionis ini berasal dari dua sumber: pertama, insignifikansi realitas, di mana identitas subjek dijadikan sebagai tanda ketidakpedulian terhadap identitas lain di luar partikularitas sosialnya, dan yang kedua adalah signifikansi berlebihan terhadap mitos imajiner, seperti identitas rasial, atau mitos mengenai kebesaran agama dan atau asal-usul subjek. Meminjam penjelasan Reiner Schürmann, berarti signifikansi yang berlebihan adalah usaha pembenaran terhadap suatu muasal ahistoris dengan referensinya ada pada subjek besar yang secara konkret hadir pada saat ini, ada pada subjek yang mengklaim, bukan pada fakta historis. ${ }^{14}$

Bentuk signifikansi yang berlebihan itu misalnya, terlihat dalam gejala fundamentalisme Islamic State in Iraq and Syria (ISIS). Apa yang bersifat ahistoris dari hasrat mereka adalah kenyataan bahwa hasrat tersebut tercabut dari pengalaman nyata masyarakat setanahnya dan semasa ini yang bersifat plural. Walaupun memiliki referensinya pada kejayaan masa lalu, namun referensi tersebut tidak pernah memadai di dalam mendorong, menggerakkan dan menarik banyak orang untuk menyatukan diri dalam gerakan tersebut. Apa yang membuat hasrat itu menghasut, menggoda bahkan menarik bagi sebagian orang adalah pada ontologi ketiadaan yakni

\footnotetext{
13 Axel Honneth, "Critical Theory," The Fragmented World of the Social: Essays in Social and Political Philosophy, ed. Charles W. Wright (Albany, NY: SUNY Press, 1995), 61-91.

14 Reiner Schürmann, Heidegger on Being and Acting: From Principles to Anarchy, terj. ChristineMarie Gros (Bloomington: Indiana University Press, 1987), 131-41.
} 
ketidakpastian yang dialami oleh semakin banyak orang di dalam bentangan relativisme masa kini. Hasrat tersebut menjanjikan suatu kepastian tertentu, dan itulah yang menggerakkan. Jadi, mitos ahistoris tersebut lahir dari sebuah ontologi ketiadaan, di mana hubungan antara kehadiran dan pikiran menghilang. ${ }^{15}$

Lagi menurut Badiou, setiap identifikasi yang dilakukan, entah melalui penciptaan atau pembentukan identitas, atau melalui upaya pengendalian sistematik oleh kekuasaan ekonomi-politik yang mendorong bertumbuhnya fundamentalisme keagamaan maupun identitas; keduanya sebagai elemen pokok sebenarnya diasalkan pada homogenisasi. Maksudnya, bahwa penghadiran sebuah ketidaksamaan di hadapan sebuah kesamaan, dalam dirinya merupakan proses penciptaan identitas. Dan penghadiran prinsip identitas dan kontradiksi sekaligus menghantar kepada sebuah korelasi baru yakni setiap konstruksi identitas bersifat destruktif, bahwa penegasan identitas mengharuskan penyingkiran non-identitas. Hal yang sama terlihat pada pengembangan modal yang selalu membutuhkan penghancuran, seringkali sebuah penghancuran yang masif dengan tujuan membangun kembali. Di sini, kita menemukan saling-hubung antara proses penyeragaman dengan proses penciptaan identitas, yakni penundukan identitas yang bersifat destruktif menghantar kepada penyeragaman. ${ }^{16}$

Bidang penyeragaman yang terartikulasi melalui kedua sumber tersebut di atas, yakni penyeragaman (pasar dan modal) dan konstruksi identitas, secara organis dibangun tanpa kebenaran. Efeknya, setiap proses kebenaran yang dihidupi masyarakat semasa merupakan variasi dari gambaran mengenai kesamaan tersebut. Hal tersebut menginterupsi setiap pengulangan yang ada sekaligus tak mampu dibatasi oleh sebuah penyeragaman. Penyeragaman tak mampu dibatasi oleh tindakan

15 Schürmann, Heidegger on Being and Acting, 141.

16 Badiou, "St. Paul, Founder of the Universal Subject," 27. 
penyeragaman yang lain. Misalnya, ISIS dengan ambisinya untuk, secara sosio-politik menyeragamkan atau menyatukan masyarakat Timur-Tengah di bawah satu payung ideologi bukanlah solusi memadai berhadapan dengan penyeragaman oleh kapitalisme. Ini berarti, bukan kebenaran yang dapat dibatasi oleh penyeragaman, bukan pula oleh konstruksi identitas, melainkan oleh sebuah singularitas yang dapat diuniversalkan. Walau begitu, patut dicatat bahwa singularitas universal tersebut berbeda dari singularitas yang dikonstruksi berdasarkan identitas maupun penyeragaman melalui pasar dan modal, melalui globalisasi ekonomi kapitalis. ${ }^{17}$

Sehubungan dengan itu, dunia sosial kita merupakan gelanggang permainan keduanya, penyeragaman oleh kapitalisme dan identitas mitologis. Dalam istilah Lacanian, berarti ketika kita berusaha memberi respons terhadap kolapsnya yang riil (the real), justru yang terjadi adalah kita masuk dalam saling-kelindan antara yang simbolik (the symbolic) dan yang imajiner (the imaginary). ${ }^{18}$ Dalam situasi semacam ini, menurut Badiou, kita mengeliminasi peristiwa, dan kesetiaan kita pada peristiwa, yang tidak lain adalah esensi subjektif dari kebenaran. Dengan begitu, dunia menunjukkan reaksi permusuhan terhadap kebenaran sejauh ia melawan identitas universal melalui penyeragaman atau kelekatan pada identitas yang dikonstruksi. Simptom permusuhan ini menjadi efek dari bersitumpang-tindihnya nama: nama dari sebuah tata laksana kebenaran yang memiliki tempatnya, disingkirkan secara paksa oleh nama lain yang dihadirkan secara langsung melalui penyeragaman. Misalnya, manajemen administratif menghapus atau menghilangkan pelayanan politik dari kehidupan nyata, korupsi menghapus keadilan sosial, seksualitas

Ibid., 27-28.

18 Bdk. ibid., 28. 
menghapus cinta. ${ }^{19}$ Di sini, kita bisa mencatat bahwa manajemen administratif, korupsi, seksualitas, maupun teknik adalah bentuk-bentuk penyeragaman yang secara nyata hadir sebagai sebuah lingkaran tertutup yang menindas.

Bila kita mengambil identitas sebagai sudut pandang penilaian, maka kita menemukan bahwa dua nama atau dua sistem yang berbeda saling berhadapan sebagai cermin satu sama lain. Seseorang melegitimasi satu hal melalui penolakan terhadap yang lain, atau dengan kata lain, terjadi reduksi progresif terhadap pertanyaan mengenai kebenaran. ${ }^{20}$ Misalnya, dalam konteks ilmu pengetahuan terjadi reduksi pengetahuan kepada keterampilan teknik; dalam konteks politik, kita melihat bangkitnya fundamentalisme religius sebagai jalan satu-satunya sistem politik yang dianggap mampu menyelesaikan segala macam problem sosial; dalam persoalan cinta, kita menemukan cinta adalah soal kebebasan menumpahkan hasrat pada objek keinginan; dan seni disingkirkan oleh sebuah pola ketertarikan kultural yang dangkal.21 Bagi Badiou, situasi ini menunjukkan bahwa tidak ada satu pun yang bersifat superior yang dialami, selain suatu fanatisme berkeyakinan yang mengarah kepada

\footnotetext{
19 Tentang hubungan antara seksualitas dan cinta, kita perlu mengingat bahwa dalam bentangan pemikiran kontemporer, terdapat gejala reduksivikasi cinta sebatas dorongan emosional atau apa yang disebut sebagai elective affinity. Oleh karena itu, sering kali mencintai disamakan begitu saja dengan dorongan hasrat (desire) yang tak terbatas. Dengan demikian, kita menemukan bahwa cinta dapat berarti promiskuitas seksual. Bdk. Axel Honneth, "Organized Self-Realization: Paradoxes of Individualization," The I in We: Studies in the Theory of Recognition, terj. Joseph Ganahl (Cambridge, UK: Polity Press, 2012), 161.

20 Badiou, Saint Paul, 6.

21 Bagi Badiou, seni, cinta, ilmu pengetahuan, dan politik adalah empat bidang kebenaran. Menurutnya, karena keempatnya menghasilkan hal-hal yang memungkinkan subjek dapat tampil secara individual atau kolektif. Setiap subjek adalah artistic, scientific, political atau amorous. Di luar keempat bidang kebenaran ini, hanya ada eksistensi atau individualitas, tetapi tidak ada subjek. Sebagaimana dicatat oleh Hallward. Lih. Peter Hallward, "Translator's Introduction," Ethics: An Essay on the Understanding of Evil, Alain Badiou, terj. Peter Hallward (London: Verso, 2002), xi.
} 
moralitas hipokrit.22

\section{Kekristenan sebagai Peristiwa}

\section{Paulus dan Teori Diskursus}

Berhadapan dengan problem homogenisasi tersebut, kita membutuhkan satu hal yang bersifat universal yang mampu memelihara pluralitas masyarakat. Tetapi di mana dan bagaimana kita mampu memahami dan mengetahui bahwa memang universalitas semacam itu ada? Menurut Badiou, kita perlu belajar dari Paulus, karena ia juga pernah mengalami situasi dengan kandungan pertanyaan yang sama dengan pertanyaan kita. Bagi Paulus, jika sebuah peristiwa sedang berlangsung, dan di situ kebenaran dinyatakan dan dipercayai, maka harus kita akui bahwa kebenaran tersebut hadir dan tampak melalui peristiwa. Mengenai hal ini, Peter Hallward mencatat bahwa konsepsi militan Paulus tentang subjektivitas apostoliknya ada dan disadari hanya melalui proklamasi sebuah peristiwa yang bermakna universal tetapi tidak objektif, yakni kebangkitan Kristus. Tidak objektif dalam pengertian bahwa keyakinan tersebut tidak terterima oleh mereka yang tidak percaya. ${ }^{23}$ Namun demikian, harus ditambahkan bahwa untuk alasan yang sama, kebenaran tersebut tidak dapat dilindungi oleh sesuatu apa pun, walau demikian ditawarkan kepada semua, universal, ditujukan kepada setiap orang tanpa definisi identiter.

Pada masa gereja awal, di tahun 50-an, berhadapan dengan keluhan bahwa beberapa orang dalam jemaat Galatia berbalik dari iman mereka, Paulus merekonstruksi satu singularitas universal dan subjek yang mendasari konsep tersebut, dengan tujuan meyakinkan mereka tentang isi

22 Badiou, "St. Paul, Founder of the Universal Subject," 28.

23 Bdk. Hallward, "Translator's Introduction," $x$. 
kepercayaan yang diberikan kepada mereka. Dalam suratnya kepada jemaat Galatia, Paulus menulis bahwa "Kristus telah menyelamatkan kita dari kutuk hukum" (Gal 3:13). Maka, Kristus adalah nama untuk peristiwa tersebut, dan kesetiaan kepada peristiwa-Kristus menghancurkan identitas natural setiap orang: "dalam hal ini, tidak ada orang Yahudi atau orang Yunani, tidak ada hamba atau orang merdeka, tidak ada laki-laki atau perempuan, karena kamu semua satu di dalam Kristus Yesus"' (Gal 3:28).

Pernyataan Paulus ini, secara eksplisit memerlihatkan tiga keadaan umum yang memengaruhi alam pikir jemaat Galatia saat itu. ${ }^{24}$ Pertama, bahwa dunia disatukan dalam sebuah struktur kekuasaan politik yang sangat kuat, yakni Kekaisaran Romawi. Dengan kata lain, dunia tersituasikan di bawah tanda yang "Satu" 25 dan Kekiasaran Romawi adalah simbolisasi yang satu itu. Satu hal yang implisit dari pernyataan tersebut adalah ketika ia menyebut "Yunani," kata ini ekuivalen dengan "bangsabangsa kafir" (Gentiles). Kedua, bahwa ada dua rezim diskursus atau episteme dominan kalau meminjam istilah Foucault, yakni diskursus Yahudi dan diskursus Yunani. Keduanya adalah apa yang disebut oleh Badiou sebagai disposisi subjektif (subjective disposition), ${ }^{26}$ yang dipengaruhi oleh alam pikir dunia yang melingkupinya. Ketiga, bahwa ada sebuah kelompok kecil, yang menjadi tempat sebuah peristiwa berlangsung, yang

24 Badiou, "St. Paul, Founder of the Universal Subject," 29; bdk. Badiou, Saint Paul, 40-54.

25 Bagi Badiou, "Satu" (One) atau disebut juga sebagai state of situation merupakan kondisi yang dibentuk oleh sebuah metastruktur, dan metastruktur itu sendiri merupakan hasil kalkulasi atau perhitungan. Sedangkan "situasi" (situation) merupakan satu presentasi keragaman yang "dihitung-sebagai-satu" dan membawa kepada forma sebuah kesatuan. Sebagai contoh, kalau kita mengambil "peristiwa Mei 1998" sebagai sebuah situasi, maka keragaman peristiwa yang terjadi pada waktu, dihadirkan pada saat ini sebagai bersifat individual, menjadi bentuk ungkapan dan sebagai tempat berbagai diskursus. "Peristiwa Mei 1998" menjadi "Counted-as-one" (as this situation). Dengan pembacaan semacam itu, memungkinkan Badiou merumuskan setiap peristiwa sebagai kebenaran, yang menentukan disposisi subjektif setiap orang.

26 Badiou, Saint Paul, 41. 
kehadirannya kabur karena diterjang badai yang datang dua episteme dominan tersebut. Inilah diskursus tandingan terhadap kedua diskursus dominan tersebut: diskursus Kristen.

Menurut Badiou, ketika Paulus berbicara mengenai Yahudi atau Yunani, dan kemudian tentang "bangsa-bangsa" (ethnoi), hal ini tidak berkaitan dengan penegasan mengenai satu lokasi historis dan objektif maupun tentang desain identitas etnis, tetapi tentang dua figur subjektif yang diperhadapkan dengan diskursus yang dihidupinya: diskursus Kristen. Diskursus Yahudi dikonstitusi atau didasarkan pada tanda, sebuah tanda yang merujuk kepada satu transendensi absolut yang melampaui dan melingkupi subjek yang menerimanya. Maka, figur subjektif dalam diskursus ini bergantung pada seorang nabi yang hadir dengan nubuatnubuatnya, yang seringkali bersifat simbolik. Sebaliknya, diskursus Yunani adalah sebuah diskursus kebijaksanaan yang ditujukan pada sikap apropriatif terhadap tatanan dunia, dan karena itu bergantung pada hubungan kehadiran antara akal (logos) dengan ada (őv). Inilah diskursus filosofis, diskursus pencinta kebijaksanaan, diskursus mengenai totalitas, di mana subjek menegaskan posisi dirinya di dalam totalitas tersebut. ${ }^{27}$

Diskursus Yahudi adalah diskursus kekecualian, karena tanda-tanda kenabian, mukjizat-mukjizatnya, dan kesadaran akan keterpilihan Israel, merujuk pada sesuatu yang transenden yang melampaui totalitas alamiah. Di sini, Yahudi sebagai sebuah bangsa dalam dirinya hanyalah sebuah tanda, mukjizat dan keterpilihan. Secara konstitutif, ia bersifat kekecualian. Kalau diskursus Yunani, mendasarkan dirinya pada sebuah tatanan kosmik yang mampu mengatur dirinya sendiri, maka diskursus Yahudi mendasarkan dirinya pada sebuah kekecualian yang bertujuan mengarahkan kondisi alamiah, untuk berbalik kembali kepada transendensi

27 Badiou, “St. Paul, Founder of the Universal Subject," 29; bdk. Badiou, Saint Paul, 41. 
ilahi sebagai sebuah tanda. Dengan demikian, orang-orang Kristen akan bergerak di antara keduanya: bukan Yudeo-Kristen, juga bukan PaganKristen. ${ }^{28}$

Ide terdalam yang mau dihadirkan oleh Paulus adalah bahwa keduanya, baik itu diskursus Yahudi maupun diskursus Yunani, memerlihatkan dua aspek dari satu gambaran yang sama, yakni gambaran mengenai kekuasaan yang menundukkan, sebuah diskursus penguasaan. Di mata Paulus yang seorang Yahudi, kelemahan diskursus Yahudi terletak dalam logika internalnya yang hanyalah valid bagi totalitas kosmik Yunani. Maksudnya bahwa karakter kekecualian yang terdapat dalam diskursus Yahudi hanyalah sebuah titik inkoherensi, yang mana dibutuhkan bagi totalitas kosmik dalam tatanan yang menopang dirinya sendiri. Yahudi hanyalah sebuah kekecualian Yunani, dan sebaliknya. Keduanya saling mengecualikan. Ada dua konsekuensi logis dari hubungan tersebut.29 Pertama, bahwa kedua diskursus tersebut tidak dapat diangkat ke level universal, karena masing-masing saling bertentangan satu sama lain. Kedua, keduanya sama-sama mengandung pengandaian bahwa kunci yang menghantar kepada keselamatan telah diserahkan kepada masing-masing dalam dunia, entah itu melalui penguasaan totalitas, yakni kebijaksanaan Yunani, atau melalui penguasaan tradisi hukum, yakni melalui nubuatnubuat dan ritual-ritual dalam ibadat Yahudi. Bagi Paulus, keduanya samasama menghalangi kita untuk mendengarkan universalitas pewartaan Kristus.

Persis di sini, kita menemukan bahwa yang ingin dilakukan oleh Paulus bukanlah sintesis atas kedua bentuk diskursus tersebut, melainkan mengarahkan kita untuk mengambil sebuah posisi diagonal di hadapan keduanya. Ia bermaksud menegaskan posisinya, yakni Kristen sebagai

28 Badiou, "St. Paul, Founder of the Universal Subject," 29; bdk. Badiou, Saint Paul, 41-42.

29 Badiou, Saint Paul, 42. 
sebuah diskursus. Dalam hal ini, Paulus meletakkan diskursus Kristen pada level yang sejajar dengan kedua bentuk diskursus terdahulu, sehingga terlihat seolah membentuk sebuah segitiga diskursus. Jika, kedua diskursus tersebut adalah diskursus Ayah, yang mengikat setiap komunitas dalam forma-forma kesetiaan seperti kosmos, kerajaan, maupun hukum dan bersifat partikular; maka diskursus Kristen adalah diskursus Putera yang potensial menjadi universal. ${ }^{30}$

Bila dicermati lebih lanjut, jelas bahwa yang satunya, Yahudi, melegitimasi dirinya berdasarkan kekuatan kekecualian, yakni kesetiaan kepada aturan-aturan tertulis yang disuarakan para nabi; dan yang lainnya, Yunani, melegitimasi dirinya berdasarkan kekuatan kebijaksanaan, yakni melalui tatanan kosmik yang disuarakan melalui para filsuf; maka, Paulus dengan pewartaannya mengenai peristiwa-Kristus sebagai diskursus baru yakni kekristenan, memahami posisinya bukan sebagai seorang nabi (prophet) dan filsuf (philosopher), melainkan sebagai rasul (apostolos). ${ }^{31}$ Rasul adalah ia yang mengatakan kemungkinan ini: bahwa karena Kristus mati dan bangkit, mereka yang percaya juga akan mati dan bangkit.

Diskursus yang disuarakan oleh seorang rasul adalah sebuah kepercayaan yang murni pada kemungkinan yang dibuka oleh peristiwaKristus. Sang filsuf mengetahui kebenaran-kebenaran abadi dalam dunia yang kontingen, sang nabi mengetahui melalui makna univokal mengenai apa yang akan datang, sekalipun kalau ia menyampaikannya menggunakan gambaran atau tanda. Rasul-lah yang mewartakan kemungkinan yang belum dikenal (unheard-of possibility), sesuatu yang bergantung pada

\footnotetext{
30 Ibid.

31 Badiou, "St. Paul, Founder of the Universal Subject," 30; bdk. Badiou, Saint Paul, 44. Pembedaan yang jelas dibuat oleh Agamben, misalnya dari konteks waktu, nabi menyangkut sesuatu di masa depan, sedangkan rasul menyangkut sesuatu yang terjadi saat ini. Lih. Giorgio Agamben, The Time that Remains: A Commentary on the Letter to the Romans, terj. Patricia Dailey (Stanford, CA: Stanford University Press, 2005), 59-61.
} 
peristiwa-rahmat. 32

\section{Peristiwa-Kristus sebagai Peristiwa-Kebenaran}

Rasul sebagai peran sekaligus kata, merupakan garis penghubung antara panggilan Paulus dan perutusannya. Bagi Paulus, peran sebagai rasul yang dianugerahkan kepadanya tidak memiliki signifikansi empiris maupun historis. Perannya berbeda dari kelompok dua belas yang "telah makan dan minum bersama-sama dengan Dia" (Kis 10:41). ${ }^{33}$ "Rasul" bagi Paulus tidak sinonim dengan "rekan Kristus" (companion of Christ). Bagi Paulus yang mengklaim hak pengajarannya hanya bagi dirinya, dan yang menurut pengalamannya sendiri "dipanggil menjadi rasul," secara eksplisit menantang pretensi dari mereka yang atas nama pengalaman atau apa yang mereka lihat, percaya bahwa merekalah penjamin kebenaran. Panggilannya sebagai rasul dinyatakan melalui peristiwa-Kristus. Panggilannya adalah murni rahmat, dan disatukan dalam peristiwa kebangkitan. Maka, Paulus sebagai rasul adalah figur diskursif dan subjektif yang disahkan melalui apa yang diwartakannya. ${ }^{34}$

Tentang hal ini, kita dapat melihatnya dalam dua pernyataan berikut: ${ }^{35}$ Pertama, menurutnya pewartaan mengenai Injil tidak melalui hikmat perkataan (ouk en Sophia logou), supaya "salib Kristus jangan menjadi sia-sia" (1 Kor 1:17). Bagi Paulus, peristiwa-Kristus merupakan sebuah kesiasiaan bila kita menilainya dari kacamata hikmat. Dari kodratnya, menurut

\footnotetext{
32 Badiou, Saint Paul, 45. Peristiwa rahmat adalah terjemahan saya atas konsep Badiou evental grace. Evental adalah satu neologisme dalam bahasa Inggris sebagai terjemahan atas kata Perancis, événemental. Kata ini berarti "memiliki-relasi-dengan-peristiwa," "berhubungandengan-peristiwa," atau "tercakup-dalam-peristiwa." Badiou, "St. Paul, Founder of the Universal Subject," 37n-38n.

33 Bdk. Slavoj Žižek, The Puppet and the Dwarf: The Perverse Core of Christianity, (Cambridge, MA: The MIT Press, 2003), 8-10.

34 Badiou, "St. Paul, Founder of the Universal Subject," 30; bdk. Badiou, Saint Paul, 44.

35 Badiou, "St. Paul, Founder of the Universal Subject," 30; bdk. Badiou, Saint Paul, 45-46.
} 
Paulus, hikmat perkataan tidak mampu menyatakan hal tersebut, bahwa peristiwa kebangkitan tidak pernah cukup diargumentasikan menggunakan hikmat manusiawi. Begitu juga, bagi mereka yang melihat dari sisi hikmat perkataan, atau yang terserap ke dalam hikmat manusiawi, peristiwa semacam itu tidak masuk akal. Dengan begitu, bagi Paulus, mereka yang percaya harus memulainya dari sebuah "peristiwa yang bernama". Peristiwa tersebut adalah kebangkitan Kristus, yang mengambil tempatnya sendiri secara historis, dan kita tidak pernah mampu memahaminya semata-mata dari hikmat manusiawi. Dalam garis penelaahan demikian berarti bukan filsuf dan nabi yang mampu mewartakan peristiwa tersebut.

Kedua, pewartaan mengenai peristiwa-Kristus, sebagai kebodohan belaka, bukanlah sebuah diskursus dalam arti yang ketat, dan sebagai sebuah peristiwa, ia berada di luar semua jangkauan hikmat manusia. Tanpa rasio dan karena itu, kita hanya memiliki kebodohan sebagai lawan hikmat. Ini disebabkan karena peristiwa-Kristus adalah kebodohan dari sisi diskursus Yunani, dan merupakan skandal bila ditilik dari sisi diskursus Yahudi. Untuk itu, jika pewartaan Paulus tersebut menyangkut peristiwaKristus, maka isi pewartaannya mengandung sebuah kelemahan, dan karena kelemahan tersebut, tidak ada figur diskursus, entah itu Yunani maupun Yahudi, yang memiliki kapasitas untuk menanggungnya, selain diskursus Kristen melalui sebuah sikap penerimaan tanpa ukuran tertentu dari sisi "hikmat manusia." Secara sederhana, hal tersebut kita temukan dalam reaksi ketidakpercayaan maupun penolakan atas fakta bahwa Tuhan mati di atas palang penghinaan. Logika kekuasaan dan kekuatan tidak mampu menerimanya sebagai kebenaran: bahwa Tuhan mati. Namun, patut dicatat bahwa kebenaran tersebut tidak dimengerti dalam term faktisitas tetapi dalam term disposisi subjektif. ${ }^{36}$

36 Badiou, Saint Paul, 45. 
Dengan begitu, kita melihat bahwa Paulus sedang mengintrodusir serangkaian fakta oposisional: kebodohan sebagai lawan hikmat, kelemahan dan tak berarti melawan kekuatan dan yang berarti, bahwa pewartaan mengenai peristiwa-Kristus mengisyaratkan kelemahan dan kebodohan. Dari sudut pandang ontologi, dalam pewartaan tersebut, kita tidak bertemu dengan Allah yang penuh kebijaksanaan maupun Allah yang penuh kekuatan. Ini bukan Allah sebagai sang Ada, bukan Allah Ada, yang melampaui segala ada. Dalam ungkapan Marion, berarti pada peristiwaKristus, kita bertemu dengan Allah tanpa Ada; bukan Allah yang menyatakan diri dalam semak-semak, yang ada sebagai ada (Ego eimi ho on), melainkan Allah yang membuka dirinya sebagai Agape (hō tēos agapēstin), Allah yang menyatakan diri di atas palang penghinaan, Allah yang memberikan diri. ${ }^{37}$

Menurut Badiou, kita dapat merangkum oposisi-oposisi yang dihadirkan oleh Paulus dalam apa yang disebut sebagai "pilihan atas nonada" (ta mé onta) dari pada apa yang ada (ta onta). Badiou menulis demikian:

God has chosen the things that are not (ta mē onta) in order to bring to nought those that are (ta onta)." That the Christ-event causes nonbeings rather than beings to arise as attesting to God; that it consists in the abolition of what all previous discourses held as existing, or being, gives a measure of the ontological subversion to which Paul's antiphilosophy invites the declarant or

\footnotetext{
37 Bdk. Jean-Luc Marion, God without Being: Hors-Texte, terj. Thomas A. Carlson (Chicago: The University of Chicago Press, 1991), 144-47. Patut dicatat di sini, bahwa penempatan secara oposisional antara peristiwa semak-semak pada Musa dengan peristiwa palang penghinaan di Golgota adalah interpretasi saya dan tidak bersifat final. Penempatan demikian hanya untuk memerjelas fakta oposisional yang dihadirkan oleh Badiou atas interpretasinya terhadap Paulus, mengingat bahwa dalam hal tertentu, Paulus tidak merujuk kepada Musa, melainkan kepada Abraham. Lih. Badiou, Saint Paul, 103. Walau begitu, dari sisi yang berbeda, peristiwa di semak-semak adalah bagian dari sejarah penyelamatan yang memuncak dalam peristiwa salib. Peristiwa semak yang dialami oleh Musa adalah sebuah peristiwa-kebenaran, dan peristiwa tersebut dalam dirinya, secara simbolik memancarkan motif fundamental rencana penyelamatan, yang memuncak dalam Inkarnasi dan peristiwa Golgota.
} 
militant. ${ }^{38}$

Posisi ini memerlihatkan pada kita bahwa Paulus adalah seorang antifilsafat, seorang musuh di dalam upaya rekonsiliasi antara diskursus Kristen dengan filsafat. Berhadapan dengan simbol kekuatan (Yunani) dan keterpilihan (Yahudi), ia mengintrodusir skandal kelemahan dan kematian Kristus yang memalukan sebagai jantung diskursus Kristen.

Dalam pandangan Paulus menurut Badiou, diskursus Kristen secara absolut membangun sebuah hubungan yang baru dengan objeknya. Diskursus ini secara efektif hadir sebagai pertanyaan mengenai figur yang lain dari yang riil. Dalam diskursus Yunani, yang riil ditemui atau dicapai melalui kekuatan argumen atau kepandaian. Maka, dalam diskursus baru ini, kita tidak dihadapkan dengan pertanyaan terkait pengetahuan, bila filsafat dilihat sebagai pengetahuan; sebaliknya bagi Paulus, diskursus yang ditandai dengan ketidaktahuan tersebut lebih terkait dengan "the advent of a subject."39 Dan figur tersebut dapat disebarkan melalui penyingkapan atas kenyataan yang tak-ter-dengar, bahwa di sana terdapat dua figur subjektif dan bukan satu, yang sering memerlihatkan perpecahan dalam diri subjek: oposisi antara jalan daging dan jalan roh, yang tidak berhubungan dengan divisi substansial tubuh/jiwa tetapi dalam divisi subjektif. ${ }^{40}$ Satu gambaran yang cukup terinci terkait divisi subjek terdapat dalam Roma 7:15-19 (Apa yang aku perbuat, aku tidak tahu ... apa yang aku benci, itulah yang aku perbuat ... apa yang tidak aku kehendaki, yang aku perbuat), yang secara sempurna memerlihatkan kondisi keterpecahan subjek di hadapan hukum, yang hanya berfungsi sebagai prinsip imputasi universal. ${ }^{41}$

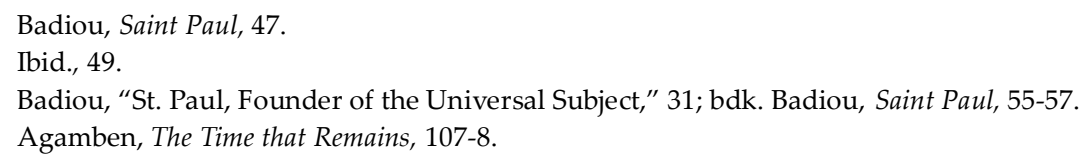


Bagi Paulus, subjek tidak dibentuk melainkan datang melalui peristiwa, maka divisi subjektif tersebut akan menentukan bagi adanya subjek dalam tindakan memilih. Memilih kematian atau kehidupan: gar phronèma tēs sarkos thanatos, to de phronèma tou pneumatos zōè (Rom 8:6). Inilah disposisi subjektif ${ }^{42}$ yang dilambangkan oleh diskursus Yunani dan diskursus Yahudi. Disposisi subjektif ini akan menentukan estetika penerimaan subjek. Menerima atau menolak perbedaan misalnya, ditentukan pula oleh disposisi subjektif subjek. Terkait hal ini, Tracy McNulty menulis bahwa posisi Yahudi dan Yunani dalam Saint Paul ini analog dengan apa yang disebut oleh Badiou sebagai "hasrat homoseksualitas" yakni hasrat di mana yang berbeda ditiadakan, hasrat penolakan terhadap perbedaan, yang liyan dieksklusi, sebagaimana dielaborasi dalam artikelnya "What is Love?"43

Dalam diskursus Yunani, objeknya adalah totalitas kosmik yang diapropriasi oleh pikiran. Sebagai konsekuensinya, yang riil menyebabkan hasrat menegaskan tempatnya, yang mana tempat berarti kekuasaan atau otoritas, dalam totalitas kosmik, dan diapropriasi oleh pikiran. Yang riil diidentifikasi dengan sebuah wewenang atau otoritas yang harus didapatkan sebagai jalan kepada hikmat. Kontras dengan hal itu, bagi Paulus, peristiwa-Kristus memerlihatkan secara jelas kesia-siaan otoritas tersebut, kalau mau disebut demikian, bahwa yang riil menampakkan dirinya justru pada titik kejatuhan setiap otoritas, dan yang tak dapat disamakan dengan hasrat untuk menemukan otoritas dalam satu totalitas homogen dalam pikiran. Ini nampak dalam pernyataan Paulus dalam 1 Kor 4:13 bahwa "kami telah menjadi sama dengan sampah dunia, sama dengan

\footnotetext{
42 Badiou, Saint Paul, 41.

43 Bdk. Tracy McNulty, "Feminine Love and the Pauline Universal," Alain Badiou: Philosophy and Its Conditions, ed. Gabriel Riera (Albany, NY: SUNY Press, 2005), 195. Artikel “What is Love?" terdapat dalam Alain Badiou, Conditions, terj. Steven Corcoran (London: Continuum, 2008), 179-98.
} 
kotoran dari segala sesuatu, sampai pada hari ini."

Dalam diskursus Yahudi, objeknya termasuk dalam pilihan, sebuah persekutuan yang luar biasa antara Allah dengan umatnya, sebuah perjanjian yang diikat, diterima dan termanifestasi dalam kesetiaan kepada hukum. Yang riil hanya bisa dialami atau diperoleh di bawah hukum. Tetapi, peristiwa-Kristus tidak sejalan dengan hukum, terlepas dari sikap respek terhadap hukum. Di situ, yang riil tak mungkin ditemukan sebagaimana terdapat dalam diskursus Yunani, begitu juga dalam bagian dari sebuah kekecualian yang tercatat dalam hukum-hukum yang telah tertulis sejak permulaan pada diskursus Yahudi. Bila otoritas itu bagi orangorang Yahudi ada pada pencarian tanda dan permintaan mukjizat, dan orang-orang Yunani pada pencarian hikmat dan memertanyakan, bagi orang Kristen adalah peristiwa-Kristus dan pewartaan tentangnya. ${ }^{44}$ Itu sebabnya, ada oposisi antara hasrat yang diwakili oleh diskursus Yahudi dan Yunani dengan cinta yang diwakili dalam diskursus Kristen. ${ }^{45}$

Bagi Paulus, kebodohan mengeluarkan kita dari hikmat Yunani melalui pembatalan rezim otoritas dan totalitas, dan membebaskan kita dari hukum. Yang riil bagi Paulus ada pada peristiwa-Kristus sebagai peristiwa par excellence, yang membuka sebuah epos baru dan mentransformasi hubungan antara posibilitas dan imposibilitas. ${ }^{46}$ Dan yang tetap ada adalah subjek yang mewartakan yang riil tersebut. Dalam tautannya dengan kebenaran berarti siapa pun yang yakin bahwa yang riil tersebut adalah peristiwa yang sebenarnya, ia masuk dalam suatu cara pandang yang melampaui perbedaan, berbeda dengan diskursus Yunani dan Yahudi yang ditandai oleh perbedaan. Inilah keyakinan universalistik dari Paulus. Perbedaan berhenti bermakna dan tidak lagi operatif di hadapan peristiwa-

\footnotetext{
44 Bdk. Badiou, Saint Paul, 58.

45 McNulty, "Feminine Love and the Pauline Universal," 195.

46 Badiou, Saint Paul, 45.
} 
Kristus, dengan begitu "tidak ada perbedaan antara orang Yahudi dan orang Yunani" (Rom 10:12). Penghadiran ketidakberbedaan ini secara tepat menghadirkan potensi universalitas dari kristianitas. Dan universalitas itu dibuka melalui kematian Yesus di salib dan kebangkitan-Nya dari mati. Itulah peristiwa-Kristus. Peristiwa sebagai rahmat (charis). ${ }^{47}$

\section{Subjek dan Singularitas Universal}

\section{Iman, Cinta, dan Harapan}

Bagi Badiou, Paulus itu seorang pemikir puitik tentang peristiwa (event), yang sebagai seorang dalam praktik dengan beragam karakternya, memerlihatkan dirinya sebagai satu figur militan karena keyakinan yang dianut dan dihidupinya. ${ }^{48}$ Bahkan dalam kejadian perpisahannya dengan Barnabas, Paulus menunjukkan sikap menolak segala bentuk kompromi, ketika diri sudah terkonstitusi oleh kesetiaan kepada prinsip kebenaran. ${ }^{49}$ Dalam kesetiaan kepada prinsip-prinsip yang dihayatinya, ia menghadirkan dirinya sebagai penyebar sebuah figur subjektif yang dikosongkan dari kedua bentuk diskursus dominan tersebut. Ini berarti, bukan mukjizat atau interpretasi rasional sebuah nubuat, bukan juga tatanan dunia dengan nilainilainya yang membentuk subjek Kristen. ${ }^{50}$

Berhadapan dengan asumsi bahwa setiap kebenaran selalu bersifat partikular, memiliki posisi yang spesifik sehingga secara formal tak dapat dibicarakan, Badiou menampilkan sosok Paulus sebagai figur yang memerlihatkan kemungkinan sebuah proses transposisional yang memampukan kita berbicara mengenai kebenaran universal. Universalisme Paulus yang melampaui partikularitas diskursus Yahudi maupun Yunani,

\footnotetext{
47 Badiou, "St. Paul. Founder of the Universal Subject," 32-33; bdk. Badiou, Saint Paul, 63.

48 Badiou, Saint Paul, 2.

49 Ibid., 26.

50 Ibid., 50 .
} 
tidak menyangkut suatu tempat tertentu, melainkan dalam pengalaman pewahyuan personal dari subjek yang dipanggil atau disentuh oleh Allah yang absconditus. Memang harus diakui, bahwa pengalaman in se dan per definitionem, selalu bersifat partikular dan unik bagi setiap orang, namun Badiou dengan inspirasi Paulus, mencoba menemukan sebuah kondisi yang dapat mengungkapkan kebenaran yang bisa diterima manusia seluruhnya.

Menurut Badiou, kemanusiaan bersifat singular, menjadi situs transposisional subjek, yang menghapus pemisahan dua posisi tanpa sesuatu yang terkandung di dalamnya dihancurkan. Maka, diskursus Yahudi dan Yunani bersifat simptomatik bagi Paulus terkait cita-cita proliferasi alteritas, di mana setiap posisi, Yahudi maupun Yunani, percaya bahwa hanya posisi itu sendiri yang memegang kunci kepada keselamatan. Keduanya memecah kemanusiaan ke dalam dua posisi oposisional. ${ }^{51}$ Tetapi universalisme Paulus mengarahkan semua kepada semua, lewatnya universalitas tersebut "must expose itself to all differences and show, through the ordeal of their division, that they are capable of welcoming the truth that traverses them." 52 Universalisme Paulus adalah universalisme yang menghancurkan tembok partikularitas penghalang kepada universalitas pewartaannya. Dalam hal ini, cintalah yang mampu mengatasi penghalang tersebut.

Cinta bagi Badiou merupakan prosedur kebenaran. ${ }^{53}$ Dalam kaitan dengan iman, yakni keyakinan yang dinyatakan, cinta menghasilkan sebuah hukum tak tertulis, satu hal yang memberi kepada kepercayaan subjek yang bersangkutan, konsistensi dan mengefektifkan postevental truth dalam pengalaman nyata. ${ }^{54}$ Dalam proses tersebut, cinta sebagai prosedur kebenaran, melaluinya setiap posisi diskursus, dari tempat yang

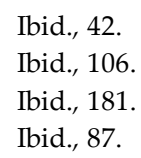


menentukan setiap pengalaman partikular dan rangkaian pengetahuan yang dimiliki, membuka kesempatan datangnya kebenaran kepada setiap manusia dalam universalitasnya. Artinya, dalam cinta tercakup transendensi atas relasi yang memerangkap setiap posisi diskursus dalam partikularitasnya, yang mengakibatkan subjek tidak mampu melangkah menuju universalitas. ${ }^{55}$ Bagi Badiou, kebenaran selalu berarti sesuatu yang bisa mencakup kemanusiaan. Itu sebabnya, di tempat lain, Badiou menegaskan dalam tulisannya bahwa cinta merupakan "the guardian of the universality of the true." 56

Dengan kata lain, ketika subjek melalui disposisi subjektifnya, yang eksplisit melalui posisi pikirannya, berada pada titik temu dengan rahmat peristiwa -iman atau keyakinan sebagai subjektivasi- ia sekalipun telah mati, akan kembali kepada kehidupan. Paulus menegaskan hal itu demikian, "jika kita telah mati dengan Kristus, kita percaya, bahwa kita akan hidup juga dengan Dia" (Rom 6:8). Kristus memeroleh kembali kekuasaannya, yang telah ditundukkan di bawah hukum dan dosa sebagai figur subjektif hukum. Ia membantu kita menemukan kembali kesatuan hidup antara pikiran dan tindakan. Pemerolehan yang dicapai oleh Kristus, mengembalikan hidup itu sendiri ke dalam hukum universal. Selanjutnya, hukum tersebut mengembalikan artikulasi hidup bagi setiap orang, sebagai sebuah jalan iman, yakni hukum yang melampaui hukum. Hukum inilah yang disebut oleh Paulus sebagai cinta. Jika dosa merupakan figur subjektif dari hukum dan kematian, maka cinta adalah figur subjektif dari kehidupan. ${ }^{57}$

Cinta sebagai prosedur kebenaran merujuk kepada keselamatan atau yang disebut oleh Paulus sebagai pembenaran karena iman. Di situ,

\footnotetext{
55 Bdk. McNulty, "Feminine Love and the Pauline Universal," 186.

56 Badiou, Conditions, 190.

57 Badiou, Saint Paul, 87-88.
} 
keselamatan dipahami sebagai pikiran yang tidak terpisah dari tindakan dan kekuatan. Kekuatan tersebut diturunkan dari pernyataan subjektif yang disebut sebagai pistis (iman atau keyakinan). Maka, keselamatan menyata ketika figur subjek yang terbagi dalam daging dan roh, memertahankan pikiran dalam kekuatan tindakan.58 Dibahasakan dalam ungkapan Yakobus berarti iman, yang dalam konteks Paulus berarti terkait pilihan disposisi subjektif pada jalan roh, tanpa perbuatan adalah mati. Cinta membawa pada keselamatan, sebab cinta memungkinkan subjek melepaskan figur subjektif yang bernama dosa, yang mana dosa dipahami sebagai permutasi tempat antara kehidupan dan kematian di bahwa efek hukum. Konsekuensinya, subjek yang mengikatkan dirinya kepada diskursus Kristen secara absolut terlepas dari hukum (lawless). ${ }^{59}$

Bagi manusia baru dalam Kristus, cinta adalah pemenuhan kesempatan yang dikerjakan oleh seseorang dengan hukum. "Cinta adalah kegenapan hukum Taurat," begitu tulis Paulus (Rom 13: 10). Ada dua hal di sini. Cinta mereduksi multiplisitas preskripsi legal, karena dalam multiplisitas perintah semacam itu, hasrat mematikan otonomi yang berhubungan dalam bentuk objek. Hanya satu, afirmatif dan maksim yang tidak objektiflah yang diperlukan. Dan yang kedua, maksim tersebut dapat dipahami secara mendalam hanya melalui iman.60 "Cintailah saudaramu seperti dirimu sendiri," merangkum dua kondisi tersebut. Satu perintah tanpa larangan adalah afirmasi otentik, dan hal ini membutuhkan iman, karena subjek yang percaya mengenai adanya kebangkitan tidak lagi memiliki alasan untuk mencintai diri sendiri. Cinta terhadap kebenaran yang hidup menciptakan subjek yang menyatakannya. ${ }^{61}$ Inilah alasannya

\footnotetext{
58 Ibid., 84; Bdk. Badiou, "St. Paul, Founder of the Universal Subject," 36.

59 Badiou, Saint Paul, 86.

60 Ibid., 89.

61 Ibid., 90.
} 
Badiou menyatakan bahwa diskursus Kristen tidak terkait dengan akumulasi pengetahuan tetapi tentang datangnya subjek (the advent of a subject). ${ }^{62}$

Seturut penalaran tersebut, cinta berada di bawah otoritas peristiwa dan subjektivasinya dalam iman, karena hanya melalui peristiwalah subjek mencapai kehidupan, bukan kematian. Cintalah yang secara tepat memungkinkan iman menjadi nyata. Badiou menyebutnya sebagai kekuatan universal dari subjektivasi sebuah kesetiaan-pada-peristiwa, dan secara tepat, bisa kita sebut bahwa kesetiaan merupakan hukum kebenaran. ${ }^{63}$ Cinta bagi Paulus adalah kesetiaan yang tepat pada peristiwa-Kristus. Maka, yang menjamin kekuatan sebuah kebenaran dan menentukan kesetiaan subjektif adalah sapaan universal relasi pada diri yang dibaharui melalui peristiwa, bukan dalam relasi in se. Inilah militansi Paulus. Proses subjektif sebuah kebenaran adalah satu dan sama dengan ekspresi cinta pada kebenaran. Dan militansi konkret dari cinta adalah sapaan universal dari apa yang mengkonstitusinya. Dengan demikian, materialitas dari universalisme adalah dimensi militan setiap kebenaran. ${ }^{64}$ Cinta (agape) mendorong subjek kepada militansi kemanusiaan universal.

Cinta sebagaimana diklaim oleh Paulus adalah yang terutama di antara iman, harap dan cinta (1 Kor 13:13). Ketika Paulus bertanya mengenai subjektivasi melalui iman, di sana, ia tidak berbicara mengenai keselamatan (sōtēria), tetapi tentang pembenaran (dikaiōma). Maka, benar bahwa manusia dibenarkan karena iman, tetapi tidak tepat juga kalau manusia diselamatkan hanya melalui cinta. Jika kita menyebut bahwa pembenaran dalam makna dasarnya terkait motif legal dari keadilan, maka keselamatan berarti pembebasan. Di sini, sebjektivasi membuka, menurut kemungkinan yang

\footnotetext{
62 Ibid., 49.

63 Ibid., 90.

64 Ibid., 92.
} 
telah dijanjikan melalui kebangkitan seseorang, sebuah ruang pembebasan; tetapi hanya cintalah, yang mengandung universalitas pewartaan, memungkinkan pembebasan itu terjadi. Cinta adalah "pleasure of truth." "Cinta bersukacita karena kebenaran - he agapē sunkairei tēi alētheiai" (1 Kor 13:6). Lalu di mana hubungannya dengan bidang harapan?65

Iman memungkinkan seseorang memiliki harapan dalam pembenaran. Paulus menulis, "karena dengan hati, orang percaya dan dibenarkan" (Rom 10:10). Iman membuka pintu kepada hal yang benar; cinta merupakan pengefektivitasan universalitas lewatnya subjek harus melaluinya (trajectory), sedangkan harapan adalah maksim yang membuat subjek dengan gembira tetap berada dalam lintasan tersebut.66 Dalam konteks ini, "dibenarkan" adalah sebuah pengadilan kebenaran yang terakhir, di mana harapan membuat kita menaruh kepercayaan pada apa yang kita yakini. ${ }^{67}$ Harapan adalah prinsip pemeliharaan, sesuatu yang tetap ada dalam bidang personal yang murni subjektif. Harapan adalah sebuah penghubung peristiwa (evental connection); ia menempatkan subjek dalam sebuah interval di antara dua peristiwa, yang terdahulu dan yang akan datang; dan subjek menjawab harapan yang terdapat dalam peristiwa yang akan datang, di dalam tatanan yang ditopang oleh peristiwa yang pertama. ${ }^{68}$ Singkatnya, dalam harapan kita memiliki keyakinan akan kebangkitan sebagai peristiwa yang akan datang, karena percaya pada peristiwa-Kristus.

Di mata Paulus, harapan bukanlah harapan di dalam sebuah kemenangan objektif. Harapan adalah kemenangan subjektif yang lahir karena iman. Kita dapat menemukannya dalam ungkapan Paulus yang

\footnotetext{
65 Ibid., 91.

66 Agamben menggambarkan hal ini demikian: "The Christian way of life is in fact not determined by worldly relations or by their content, but by the way, and only by the way, in which they are lived and are appropriated in their very impropriety." Lih. Agamben, The Time that Remains, 34.

67 Badiou, Saint Paul, 93.

68 Ibid., 94.
} 
menggambarkan militansinya pada sebuah kebenaran: "kita bermegah dalam pengharapan akan menerima kemuliaan Allah." Lebih jauh, "kita malah bermegah juga di dalam kesengsaraan kita, karena kita tahu, bahwa kesengsaraan itu menimbulkan ketekunan, dan ketekunan menimbulkan tahan uji, dan tahan uji menimbulkan pengharapan. Dan pengharapan tidak mengecewakan" (Rom 5: 2-5). Di sini, harapan sebagai dimensi subjektif subjek dikaitkan dengan tantangan yang harus dilalui saat ini dan di sini. Harapan adalah kesabaran dalam kesetiaan, keuletan cinta menghadapi berbagai ancaman dan tantangan. Harapan adalah kemenangan kesetiaan yang sangat subjektif, kesetiaan kepada kesetiaan. Itu sebabnya, harapan bukanlah sebuah utopia, tetapi terkait dengan keterlibatan langsung subjek dalam pengalaman nyata subjek yang bersifat spasio-temporal. ${ }^{69}$

\section{Universalitas Subjek Singular}

Pembenaran adalah suatu keadaan yang copresent dengan tujuan universal dari cinta. Itu berarti bahwa pembedaan konseptual yang dibuat oleh Paulus tidak bertujuan mengarahkan kita kepada suatu pembedaan yudisial antara mereka yang diselamatkan dengan mereka yang dihukum. Sebaliknya, melalui harapan sebagai keyakinan di dalam militansi kesetiaan, Paulus ini menegaskan bahwa pembedaan tersebut justru mengafirmasi fakta bahwa setiap kemenangan dalam kenyataan adalah kemenangan bagi setiap orang. Di sini, kita bisa melihat bahwa harapan adalah modalitas subjektif dari kemenangan yang bersifat universal. Hanya cinta sebagai sebuah kekuatan umum dari cinta-akan-diri, mampu menghantar setiap orang kepada siapa saja. Cinta yang menghantar pada kemenangan adalah konstruksi kehidupan pikiran, di dalamnya harapan menghubungkan subjektivitas keselamatan yang mengandung kesatuan pikiran dan

69 Bdk. Badiou, Saint Paul, 95. 
kekuatan, sebagai satu universalitas di hadapan beragam tantangan. ${ }^{70}$ Dengan begitu, setiap bentuk kemenangan sekalipun terlokasi, adalah sesuatu yang universal. Universal selalu memersatukan (uniting), tidak sebagai sebuah susunan. Ia melampaui setiap posisi partikular tanpa menghancurkan partikularitas tersebut. Ini berarti, subjek, kita, Anda dan saya mampu mengidentifikasi dirinya sendiri dalam singularitasnya sebagai subjek, di dalam ekonomi keselamatan, hanya sejauh ekonomi itu sendiri adalah universal. ${ }^{71}$

Universalisme merupakan produk subjektivitas absolut (non-relatif), yang tak membedakan perkataan dan tindakan, pikiran dan kekuatan. Pikiran (keyakinan) menjadi universal hanya ketika ia mengarahkan dirinya kepada semua orang, dan menempatkan dirinya sebagai kekuatan melalui pengarahan tersebut. Dalam setiap momen tersebut, tercakup juga militansi soliter yang disatukan menurut yang universal, dengan hasilnya adalah memasukkan yang lain (the Other) melalui yang sama (the Same). Dalam hal ini, Paulus ingin menunjukkan bagaimana sebuah konsepsi universal bertumpu pada sebuah cita-cita proliferasi alteritas (Yahudi, Yunani, tuan, hamba, laki-laki, perempuan), menghasilkan yang sama (the Same) dan kesederajatan (tidak ada lagi Yahudi atau Yunani, tidak ada hamba atau orang merdeka, laki-laki atau perempuan). Dalam hal ini, universalitas bukanlah negasi atas partikularitas, tetapi lintasan melaluinya subjek menjaga jarak dengan partikularitasnya. Universalitas adalah upaya subjek mengosongkan diri (subtraction) dari partikularitasnya, menciptakan

\footnotetext{
70 Di sini menjadi jelas juga bahwa Paulus dalam diskursus Kristennya, berhasil mengatasi konsepsi cinta (eros) yang khas diskursus Yunani dengan konsepsi cinta (agape) yang khas Kristen. Dengan begitu, ia bisa membantu subjek untuk tidak terjebak dalam narsisme individual ketika ia bicara tentang cinta-diri. Anders Nygren menulis bahwa Agape adalah "transvaluation of all ancient values." Penjelasan lengkap mengenai perbedaan ini dapat dibaca pada Anders Nygren, Agape and Eros, terj. Philip S. Watson (Philadelphia: The Westminster Press, 1953).

71 Badiou, Saint Paul, 96.
} 
kesederajatan dan menempatkannya dalam pikiran. Dalam hal ini, perbedaan-perbedaan merupakan tanda material dari yang universal. ${ }^{72}$

Gagasan Badiou tentang subjek yang mengosongkan diri (subtraction) dari partikularitas, sehingga mampu mencapai level "yang Sama", dalam penilaian saya, analog dengan gagasan antropologi filosofis Helmuth Plessner mengenai "forma posisi eksentrik" subjek. Plessner memaksudkan konsep ini mengenai kapasitas rasional subjek untuk mengarahkan diri dalam dua arah sekaligus: ke dalam terkait kapasitas refleksifnya, dan ke luar terkait kapasitasnya untuk membedakan diri dengan dunia. ${ }^{73}$ Dalam konteks singularitas universal, saya menginterpretasi forma posisi eksentrik Plessner sebagai kapasitas untuk mengangkat diri atau mengeluarkan diri dari partikularitasnya. Eksentrik berarti subjek dapat menjauh, atau mengeluarkan diri dari pusat partikularitasnya sendiri, untuk mencapai kesadaran tentang kesamaan antarmanusia. Kesamaan Paulinian, tidak dalam pengertian natural-fisik, melainkan pada level imanen atau kesadaran, dalam tautannya dengan apa yang saya sebut sebagai motif fundamental peristiwa-Kristus: tidak ada orang Yahudi atau orang Yunani (etnik), tidak ada hamba atau orang merdeka (ketidakadilan sosial), tidak ada laki-laki atau perempuan (perbedaan seksual). ${ }^{74}$

Badiou menulis bahwa setiap partikularitas berhubungan dengan konformitas, terkait dengan kecenderungan "menyerupakan diri" dengan orang-orang dalam partikularitas masing-masing, tetapi mengandung penolakan terhadap partikularitas lain, sekaligus mendefinisikan cara

\footnotetext{
72 Ibid., 109.

73 Lih. Helmuth Plessner, I Gradi Dell'organico e L'uomo: Introduzione all'antropologia Filosofica, ed. Vallori Rasini, (Torino, Italia: Bollati Boringhieri, 2006), 312 et seq.

74 Motif fundamental berarti faktor di dalam sebuah keutamaan, yang membuat pandanganpandangan partikular atau sebuah sistem memiliki karakternya yang khas, terbedakan dari semua hal lain. Motif fundamental adalah makna yang berada dibalik forma-forma lahiriah dan ekspresi, yang memberi signifikansi, sebuah konstitusi esensial yang membuat sesuatu ada sebagai mana adanya, sesuatu ada secara otentik. Bdk. Nygren, Agape and Eros, 27 et seq.
} 
penguasaannya atas universum. ${ }^{75}$ Dalam tatanan prosedur kebenaran, di mana masyarakat digenggam oleh kebenaran, imperatif universalitas tidak ditempatkan di bawah aspek-aspek partikularitas. Ini membantu subjek untuk mampu mentransendensi perbedaan-perbedaan. Ketika berhadapan dengan beragam kebiasaan atau pandangan, subjek menghadirkan dirinya dalam bingkat "indifference that tolerates differences."76 Maksim fundamentalnya adalah " $m \bar{e}$ eis diakriseis dialogismōn - jangan memperdebatkan pandangannya" (Rom 14:1). Di sini, pikiran universal terkait dengan diakrisis yakni kapasitas "pembedaan perbedaan" (discernment of differences). Maka, di hadapan partikularitas, Paulus memesan “janganlah kamu menjadi serupa dengan dunia ini, tetapi berubahlah oleh pembaharuan budimu (Rom 12:2).

\section{Tanggapan Kritis}

Slavoj Žižek menulis bahwa kalau kita mengambil pemikiran Badiou mengenai Paulus sebagai sebuah "situasi-keberadaan" yang dibagi ke dalam empat bidang kebenaran (cinta, seni, ilmu pengetahuan, dan politik), agama Kristen sendiri merupakan "pilinan simptomatik" dari beragam elemen yang tercakup dalam keempat bidang kebenaran tersebut, tanpa satu bidang pun diakui sebagai bagian darinya. Ini memerlihatkan bahwa "kebenaranperistiwa" berada di dasar gestur ideologis interpelasi subjek, yang menjadi bagian dari situasi keberadaan subjek pengikut kebenaran. Maju setapak lagi dari sini, kita akan menemukan bahwa model paradigmatik mengenai "kebenaran-peristiwa" tidak menyangkut agama-agama secara umum, tetapi spesifik menyangkut agama Kristen, yang berpusat pada peristiwa kedatangan dan kematian Kristus. Dengan interpretasi semacam ini,

\footnotetext{
75 McNulty, "Feminine Love and the Pauline Universal," 197.
}

76 Badiou, Saint Paul, 99. 
menurut Žižek, Badiou dapat dibaca sebagai salah satu penulis besar dogmatisis Katolik dalam tradisi Perancis mulai dari Blaise Pascal (16231662) dan Nicolas Malebranche (1638-1715). ${ }^{77}$

Menurut Žižek, dalam pembacaannya atas Paulus menghantar Badiou untuk menempatkan Kristianitas dalam dua posisi dasar yang sejajar. Di satu sisi, Kristianitas ditempatkan pada posisi sebagai positivitas Ada, dalam suatu tatanan kosmos yang ditata melalui hukum-hukumnya, yang merupakan ruang lingkup keterbatasan dan kematian. Pada sisi lain, Badiou menegaskan bahwa tidak semuanya seperti yang terlihat, karena di sana ada dimensi lain, yakni dimensi mengenai hidup yang benar dalam cinta, yang memampukan kita mencapai semua hal melalui rahmat ilahi. Kedua sisi ini mencakup sebuah hukum impersonal dari keadilan kosmik di satu sisi, dan cinta sebagai kebenaran universal yang hanya bisa digapai melalui bantuan rahmat ilahi di sisi lain. Dari sana, kita bisa mengetahui kalau revelasi Kristen memerlihatkan bahwa kita tidak dibatasi hanya pada positivitas Ada, namun bagaimana dari waktu ke waktu, di dalam lintasan kontingensitas dan tak terprediksikan, sebuah kebenaran-peristiwa mampu membuka bagi kita kemungkinan untuk berpartisipasi dalam kehidupan yang lain berdasarkan warisan kepercayaan pada kebenaran-peristiwa.

Hal menarik yang patut dicatat adalah bagaimana Badiou bergerak melingkar antara standar oposisi hukum sebagai universal dan rahmat atau kharisma sebagai partikular. Hal ini terkait dengan gagasan bahwa kita semua terangkum di dalam satu universalitas hukum ilahi, sekalipun hanya sedikit saja dari kita yang disentuh oleh rahmat dan karena itu diselamatkan. Dalam interpretasi Badiou atas Paulus, hukum itu sendiri bersifat universal sejauh dinampakkan, tetapi pada puncaknya, pada

\footnotetext{
77 Slavoj Žižek, "Paul and the Truth Event," Paul's New Momment: Continental Philosophy and the Future of Christian Theology, eds. John Milbank, Slavoj Žižek, dan Creston Davis (Grand Rapids, Michigan: Brazos Press, 2010), 88.
} 
momen putusan aplikatifnya selalu bersifat konkret partikular (partikular universal): tatanan legal selalu menuntut hak dan kewajiban spesifik dari kita, hukum selalu mendefinisikan komunitas khusus sekaligus mengekslusi yang lain, seperti komunitas etnik; sedangkan rahmat ilahi secara jelas sangat universal, non-ekslusif, diberikan kepada semua orang tanpa tergantung pada ras, seks, status sosial dan sebagainya, ${ }^{78}$ suatu universalitas singular.

Kritik lain datang dari Dale Martin, yang melihat bahwa interpretasi Badiou dan Žižek atas Paulus tidak tepat. Merujuk pada pernyataan Badiou bahwa "the new universality bears no privileged relation to the Jewish community,"79 dan pernyataan Žižek bahwa "Saint Paul conceives of the Christian community as the new incarnation of the chosen people: it is Christians who are the true "children of Abraham,"80 Martin menyatakan bahwa isi pewartaan yang sebenarnya adalah tentang keselamatan orang-orang Yahudi di masa depan. Berdasarkan pernyataan "seluruh Israel akan diselamatkan," (Rom 11:26a), Martin melihat bahwa, pertama, Paulus adalah seorang universalis dalam pengertian bahwa peristiwa keselamatan tersebut menyangkut keselamatan seluruh Israel. Dan yang kedua, universal dalam pengertian bahwa orang-orang bukan-Yahudi atau bangsa-bangsa lain akan dicangkokkan (grafting) pada masyarakat Israel.

Bagi Martin, universalitas Paulus tidak menyangkut subtraction tetapi menyangkut grafting. ${ }^{81}$ Untuk itu, tegas Martin, universalitas Paulus harus dipahami dalam konteks monoteismenya dan tidak dalam konteks filsafat. ${ }^{82}$

\footnotetext{
78 Žižek, "Paul and the Truth Event," 94.

79 Badiou, Saint Paul, 23.

80 Žižek, The Puppet and the Dwarf, 130.

81 Dale Martin, "The Promise of Teleology, the Constraint of Epistemology, and Universal Vision in Paul," St. Paul among the Philosophers, eds. John D. Caputo dan Linda Martín Alcoff (Bloomington: Indiana University Press, 2009), 98, 100.

82 Martin, "The Promise of Teleology, the Constraint of Epistemology, and Universal Vision in Paul," 93.
} 
Caputo meringkasnya demikian, bahwa universalisme dalam konsepsi Paulus tidak dalam bingkai konsepsi filosofis tentang universalitas dalam pandangan modern, tetapi terkait dengan motif teologis dari rencana Allah bagi keselamatan universal. Dalam arti ini, Paulus memahami dan memaknai karya misinya sebagai sebuah usaha pencangkokan gentiles ke dalam Israel. Dalam misinya ini, Paulus tidak bermaksud menghancurkan keragaman etnisitas, tetapi mencangkokkan mereka semua ke dalam satu bangsa yang benar - pohon zaitun Israel. ${ }^{83}$

Dengan dua tanggapan di atas, saya ingin memberi dua tanggapan kecil terhadap pandangan Badiou juga Martin di atas. Dengan keyakinan bahwa pada era ilmu pengetahuan ini, orang tidak mampu menerima kebenaran faktual mengenai kebangkitan sebagai forma kebenaranperistiwa (bandingkan dengan ketawa ejek beberapa filsuf Epikurean dan Stoisis terhadap Paulus ketika ia mengunjungi Athena), telah mendorong Badiou untuk menyebut bahwa "resurrection ... is just a mythological assertion."84 Dalam penilaian saya, dengan melihat kebangkitan sebagai sebuah penegasan mitologis atau sebagai dongeng, maka universalisme yang mau dibangun oleh Badiou diletakkan di atas sebuah ideologi kekosongan. Hal ini sejalan dengan pandangan Žižek bahwa "an Event does not possess any ontological guarantee. It cannot be reduced to (or deduced, generated from) a (previous) situation; it emerges "out of nothing" (the Nothing that was the ontological truth of this previous situation). "85

Dari sudut pandang ontologis, dengan menekankan peristiwa (event), berarti Badiou memberikan tempat utama kepada aktivitas (activity), ketimbang ada (Being). Artinya, dalam kaitannya dengan kebenaran, maka aktivitaslah yang mendefinisikannya. Problemnya adalah kalau kita

\footnotetext{
83 Caputo, "Postcards from Paul: Subtraction versus Grafting," 20.

84 Badiou, Saint Paul, 107.

85 Žižek, "Paul and the Truth Event," 83.
} 
menyingkirkan ada (Being) dan mencoba merumuskan kebenaran melulu dari sisi aktivitas, benarkah setiap peristiwa dapat disebut sebagai peristiwakebenaran? Ini disebabkan karena kita kehilangan referensi, dalam bahasa Badiou berarti kita hanya melakukan presentasi tanpa representasi, karena setiap peristiwa adalah sebagai Counte-as-one (satu situasi dalam keunikan dan perbedaannya). Bila direntangkan pada bidang politik, maka dengan mendasarkan dirinya hanya pada ideologi kekosongan, maka universalitas singular yang ingin Badiou kemukakan, sebagai kritik terhadap problem keserbasamaan atau penyeragaman oleh kapitalisme global maupun mitologis identitas, hampir tidak memadai. Gagasannya cenderung mengarah kepada suatu keyakinan ahistoris dan ini berarti tidak jauh berbeda dengan bentuk-bentuk fundamentalisme lainnya yang kehilangan hubungan antara kehadiran (presensi) dengan ada (Being).

Lebih lanjut, menjawab kritik Martin terhadap Badiou, saya menampilkan apa yang saya sebut sebagai meta-abstraksi dalam gagasan Paulinian Badiou. Ini adalah abstraksi di atas abstraksi, yang kalau ditilik dari sisi epistemologi idealisme, menghantar kita bergerak ke dalam sebuah imanentisme teoritis, mengingat Badiou sendiri menyatakan bahwa yang berpotensi menjadi universal adalah apa yang merupakan kekecualian imanen.86 Saya menilai gagasan ini sebagai sebuah imanentisme sebagai fenomenologi, lewatnya kesadaran subjek mengarahkan dirinya keluar kepada sosialitas konkret. Meta-abstraksi ini merupakan sebuah aporia pencangkokan kalau mau disebut demikian, yakni pencangkokan tanpa pencangkokan. Gagasan aporia ini merujuk pada pernyataan Paulus bahwa "Yahudi sejati ialah dia yang tidak tampak keyahudiannya" (Rom 2:29). Selain itu dalam pernyataan tersebut, Paulus sedang mengarahkan maksudnya kepada subjek imanen, satu meta-subjek: non-Yahudi sebagai non

86 Badiou, Saint Paul, 111. 
non-Yahudi, atau bercermin pada Agamben berarti subjek Paulus adalah subjek "non non-non-Yahudi", juga "non non-non-Yunani."87 Maka, bagi saya, tidak seperti klaim Martin bahwa misi Paulus adalah pencangkokan bangsabangsa ke dalam Israel, melainkan Israel adalah tempat kita bercermin tentang bagaimana seharusnya kita terlibat secara konkret dalam masyarakat. Universalitas singularnya tidak dalam pengertian Kantian yang ahistoris dan soliter, tetapi subjek yang terlibat secara konkret namun memancarkan universalitas kemanusiaan tanpa menghancurkan partikularitas identitasnya. Ini adalah subjek universal konkret.

\section{Kesimpulan}

Kita mungkin menyebut Persatuan Indonesia atau Negara Kesatuan tetapi penyebutan itu bersifat sangat semantik dan lahir dari sebuah proses homogenisasi sosial dan ekonomi, yang mengakibatkan penindasanpenindasan kontemplatif atas masyarakat kecil yang tertutup aksesnya kepada keadilan. Konstitusi kita bicara mengenai persatuan Indonesia, yang berarti tersedia ruang bagi segala ekspresi perbedaan. Tetapi dalam pengalaman nyata, kita tidak bertemu dengan cara hidup yang menjunjung persatuan, melainkan kesatuan yang memprioritaskan keserbasamaan dan keseragaman. Dalam ungkapan Badiou berarti politik direduksi kepada aspek-aspek administratif yang cenderung menyeragamkan (suture). Ini berarti kita tidak berhadapan dengan cara pandang universalitas yang memelihara perbedaan tetapi cara pandang generalisasi yang meniadakan perbedaan. Itu sebabnya, sering kita berhadapan dengan apa yang disebut sebagai sebuah kesibukan sosial tanpa solidaritas, penolakan terhadap mereka yang berbeda pandangan ideologi maupun keyakinan. Apa yang nyata dari situasi tersebut adalah bahwa masyarakat terjebak dalam suatu

87 Bdk. Agamben, The Time that Remains, 44-5. 
bentuk otomatisme sosial, atau sebentuk reifikasi sosial yang melahirkan sikap disrespek terhadap orang lain.

Dalam ungkapan Badiou berarti hukum-hukum sosial yang terterima begitu saja, yang menghantar subjek ke dalam suatu homogenisasi perilaku, menghadirkan hasrat dengan sebuah otonomi yang mencukupi bagi subjek hasrat: hasrat homoseksualitas, hasrat menolak perbedaan. Dari perspektif otonomi tersebut, subjek dilemparkan pada sebuah tempat kematian, sebuah dunia di mana semua melawan semua. Hukum-hukum, kebiasaankebiasaan atau partikularitas-partikularitas yang menolak perbedaan merupakan bentuk kehidupan yang diserahkan pada kendali hasrat. Walau begitu, dalam pengalaman nyata, hasrat merepresi subjek mengakibatkan disposisi subjektif subjek cenderung pada jalan kematian. Kematian di sini berhubungan dengan dosa dalam kosakata Paulus, dan dosa berarti kehidupan hasrat sebagai otonomi, sebagai otomatisme. ${ }^{88}$ Subjek menjadi serupa dengan dunia (Rom 12:2), dan secara politik berarti subjek ditundukkan ke dalam homogenisasi yang menindas.

Jika kita meringkasnya berarti tindakan-tindakan manusia menurut Badiou selalu terjadi dalam dua bidang sub-sphere. Pertama, bidang ordinary, yakni bidang kehidupan yang biasa, umumnya dan yang secara tertentu memerlihatkan realitas sosial terkait hasrat menjadi otonom, hasil otomatisme sosial. Inilah, bidang yang berhubungan dengan apa yang disebutnya sebagai state of situation, yang secara sosial-politik tidak terlepas dari upaya pemeliharaan status quo. Yang kedua, adalah bidang kekecualian (exceptional realm), bagaimana subjek singular tidak menjadi serupa dengan dunia, bagaimana subjek mampu mengambil jarak dengan adat-istiadatnya, dengan kerumunan keagamaannya, dengan kerumunan sosial, bahkan secara historis, bagaimana subjek mampu keluar dari arus atau kontinuitas

88 Badiou, Saint Paul, 79. 
waktu yang ada, mampu mengambil posisi berbeda. Membahasakan kedua bidang Badiou ini dalam term heideggerian berarti bidang ordinary adalah bidang das Man, di mana subjek tenggelam dalam kerumunan massa, sedangkan bidang exceptional adalah bidang otentisitas kehadiran Dasein.

Di bidang exceptional inilah, tersedia ruang inovasi singular, dalamnya berlangsung peristiwa dan kebenaran yang membuat subjek dengan militansi pada universalitas kebenaran memancar keluar, tempat subjek merevelasikan dirinya dalam otentisitas kehadirannya. Konsepsinya mengenai universalisme singular berada dalam bidang ini, di mana subjeksubjek singular mengupayakan singularitas politik yang mengarah kepada keadilan dan perdamaian. Subjek mengeksplorasi bidang-bidang tak biasa demi merajut hidup berdamai dan berkeadilan. Inilah bidang di mana, semua orang percaya bahwa partikularitas-partikularitas sosial memunculkan pluralitas di dalam the political, bahwa karakter ontologi dari politik adalah pluralitas pandangan maka secara logis dapat diputuskan. Singkatnya, ketika kekuasaan menjaga konsistensi (ontologi) dan keputusan (logis), maka Badiou mengartikulasi sebuah singularitas yang bersifat universal, singularitas politik, di mana secara ontologi mengandung inkonsistensi dan secara logis mengandung ketakterputusan (undecidable). Itu sebabnya ia menemukan dalam diri Paulus hubungan antara proposisi mengenai subjek dan sebuah interogasi terkait hukum dan berusaha keluar dari apa yang saya sebut sebagai jebakan "subjek hasrat." 89 Gestur politicoreligius Paulus memerlihatkan subtraksi kebenaran dari cengkeraman komunitas seperti masyarakat tertentu, sebuah teritori, bahkan dari kelas sosial tertentu.

Membaca pluralisme Indonesia dalam bingkai Badiouan, maka tidak ada pluralitas yang satu, yakni kesatuan Indonesia yang cenderung kepada

89 Ibid., 5. 
homogenisasi, sebaliknya kita berhadapan dengan kepluralitasan pluralitas plurality of pluralities, yang menuntut kita mengupayakan persatuan. Singkatnya, dalam konteks Indonesia, seharusnya pluralitas tidak dilihat hanya sebatas sebagai fakta terberi (fact), tetapi sebagai faktisitas (facticity) yang perlu kita perjuangkan bersama. Setiap subjek mendefinisikan dirinya melalui relasi singularnya dengan peristiwa-kebenaran dan tidak melalui saling-pertukaran pandangan di bawah norma-norma umum pluralisme yang selalu menghomogenkan. Singularitas universal ini mencoba mengatasi problem homogenisasi melalui pasar maupun fundamentalisme religius yang selalu melahirkan destruksi sosial. Singularitas universal mencoba masuk dalam dunia yang terhubung satu sama lain, global village, tanpa solidaritas atau persaudaraan. Singularitas universal adalah bahasa mengenai solidaritas dan persahabatan antar-warga, subjek universal konkret seperti tampak dalam sosok seorang Gus Dur. 